\title{
Super Antibiotics, Part VI: Hyperforin, Revision of Stereochemistry. Short Communications
}

\author{
Ilia Brondz \\ Norwegian Drug Control and Drug Discovery Institute (NDCDDI), Ski, Norway \\ Email: ailia.brondz@gmail.com
}

How to cite this paper: Brondz, I. (2018) Super Antibiotics, Part VI: Hyperforin, Revision of Stereochemistry. Short Communications. International Journal of Analytical Mass Spectrometry and Chromatography, 6, 37-39.

https://doi.org/10.4236/ijamsc.2018.62003

Received: March 22, 2018

Accepted: June 5, 2018

Published: June 8, 2018

Copyright $\odot 2018$ by author and Scientific Research Publishing Inc. This work is licensed under the Creative Commons Attribution-NonCommercial International License (CC BY-NC 4.0). http://creativecommons.org/licenses/by-nc/4.0/

\begin{abstract}
This short communication is an overview and revision of previous published papers about the relative and absolute stereochemistry of hyperforin and discovery of a new isomer of hyperforin that has been named perforatrin.
\end{abstract}

\section{Keywords}

Revision, Relative and Absolute Stereochemistry, Hyperforin, Perforatrin

\section{Introduction}

The antibiotic properties of the antibacterial substances known to be present in species of the genus Hypericum (Hypericaceae (Guttiferae)), is well established. Extracts from the plant Hypericum perforatum L. have been used to preserve food [1], treat infections [2], as immunomodulating agent [3] [4] [5] [6] and for many other medical purposes. One active constituent designated hyperforin, was isolated and characterized in 1971 [7]. The absolute configuration was suggested in 1975-1976 [8]. The report [9] presents arguments suggesting that a crystal structures determination of the 3.5-dinitrobenzoate ester [10] and $p$-bromobenzoate ester [11] are in contradiction with the proposed absolute configuration published in [8]. In order to obtain direct evidence for the absolute stereochemistry of hyperforin, a single crystal structure analysis of its $p$-bromobenzoate ester has been carried out [11] and has been supported by GC-MS [9]. In accordance to X-ray crystallography [11], it may be pointed out that the difference between the earlier suggested absolute configuration by Bystrov et al. [7] and absolute configuration [8] suggested also by Bystrov et al. in 1975-1976, the absolute configuration resolved by X-ray crystallography and presented by Brondz et al. in [11], is that stereochemistry at the two chiral centers is different. The same is supported by [10] [11] [12] [13] [14]. 


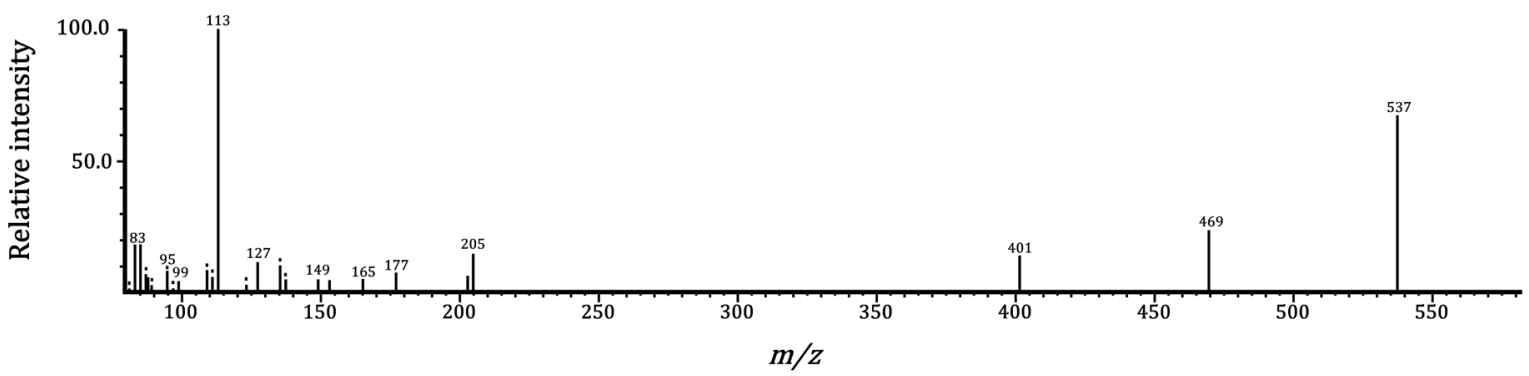

Figure 1. MS spectrum of hyperforin by using chemical ionization.

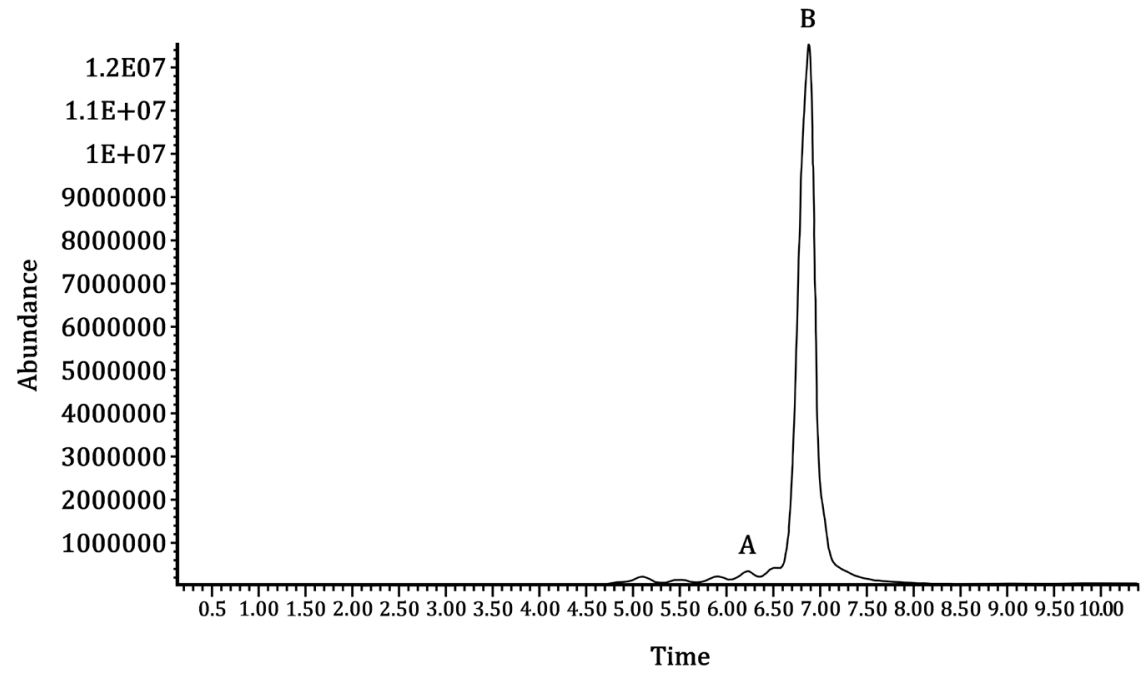

Figure 2. The peak A is perforatrin and peak B is hyperforin.

First time MS spectrum of hyperforin has been obtained by using chemical ionization (CI) [1] (Figure 1).

In following publication [9] has been discovered two isomers of hyperforin, the major is hyperforin and the minor was named perforatrin (Figure 2).

The stereochemistry proposed by Bystrov et al. in [7] and [8] was wrong, comparison of absolute configuration of hyperforin has been proposed by Brondz et al. [11] and supported by Brondz [9] [12]. In independent research [13] and [14] conclusively has been demonstrated correctness of stereochemistry of hyperforin proposed by Brondz in [9] [10] [11] [12].

\section{Acknowledgements}

Figure 1 and Figure 2 was republished from publication [9].

\section{References}

[1] Brondz, I. (1979) Antibiotikumet "Hyperforin" og andre innholdsstoffer i drogen Hypricum perforatum L. Thesis (Cand. Pharm.). University of Oslo, Oslo. (In Norwegian)

[2] Gurevich, A.I., Dobrynin, V.N., Kolosov, M.N., Popravko, S.A., Ryabova, I.D., Chernov, B.K., Derbentseva, N.A., Aizenman, B.E. and Garagulya, A.D. (1971) 
Hyperforin, an Antibiotic from Hypericum perforatum L. Antibiotiki Kimioterapi, 16, 510-513.

[3] Brondz, I. (1986) Lecture Entitled: The Influence of Hyperforin on Phagocytosis of E. coli by Human Polymorphonuclear Neutrophils in Vitro. Norlændska Infektionssjkdomar Symposium, Vårmøteti Sundsvall, 14-15 May 1986.

https://www.researchgate.net/publication/233795016_The_influence_of_hyperforin _on_ph agocytosis_of_Ecoli_by_human_polymorphonuclear_neutrophils_in_vitro

[4] Brondz, I. (1987) Influence of Hyperforin upon Phagocytic Functions in Human Polymorphonuclear Leucocytes. 4th International Conference on Chemistry and Biotechnology of Biological Active Natural Products, Budapest, 10-14 August 1987, 119.

[5] Brondz, I. (2012) Enhancement of the Immunity in AIDS and Other Immunocompromised Patients by Hyperforin an Antibiotic from Hypericum perforatum L. 2nd ARIP European Conference on Antimicrobial Resistance \& Infection Prevention, Vilnius, 4-5 October 2012, 60.

[6] Brondz, I. and Brondz, A. (2012) Recent Enhancement of the Immunity in AIDS and Other Immunocompromised Patients by Hyperforin an Antibiotic from Hypericum perforatum L. (In Vitro Model) Part I. Journal of Biophysical Chemistry, 3, 304-310. https://doi.org/10.4236/jbpc.2012.34037

[7] Bystrov, N.S., Chernov, B.K., Dobrynin, V.N. and Kolosov, M.N. (1975) The Structure of Hyperforin. Tetrahedron Letters, 16, 2791-2794. https://doi.org/10.1016/S0040-4039(00)75241-5

[8] Bystrov, N.S., Dobrynin, V.N., Kolosov, M.N., Chernov, B.K., Chervin, I.I. and Yakovlev, G.I. (1976) Stereokhimiya Antibiotika Hyperforina. Doklady Akademii Nauk SSSR, 226, 338-341.

[9] Brondz, I. (2017) Super Antibiotics, Part IV. Hyperforin, Relative and Absolute Stereochemistry Elucidated by Gas-Chromatography Mass-Spectrometry with Supersonic Molecular Beams. International Journal of Analytical Mass Spectrometry and Chromatography, 5, 70-85. https://doi.org/10.4236/ijamsc.2017.53005

[10] Brondz, I., Greibrokk, T., Groth, P.A. and Aasen, A.J. (1982) The Relative Stereochemistry of Hyperforin-An Antibiotic from Hypericum perforatum L. Tetrahedron Letters, 23, 1299-1300. https://doi.org/10.1016/S0040-4039(00)87088-4

[11] Brondz, I., Greibrokk, T., Groth, P. and Aasen, A.J. (1983) The Absolute Configuration of Hyperforin, an Antibiotic from Hypericum perforatum L., Based on the Crystal Structure Determination of its p-Bromobenzoate Ester. Acta Chemica Scandinavica, A37, 263-265. https://doi.org/10.3891/acta.chem.scand.37a-0263

[12] Brondz, I. (2017) Super Antibiotics: Part III. Hyperforin, Revision of the Relative and Absolute Stereochemistry Presented by Bystrov et al. Voice of the Publisher, 3, 15-24. https://doi.org/10.4236/vp.2017.32002

[13] Shimizu, Y., Shi, S.-L., Usuda, H., Kanai, M. and Shibasaki, M. (2010) Catalytic Asymmetric Total Synthesis of ent-Hyperforin. Angewandte Chemie International Edition, 49, 1103-1106. https://doi.org/10.1002/anie.200906678

[14] Adam, P., Duilio Arigoni, D., Bacher, A. and Eisenreich, W. (2002) Biosynthesis of Hyperforin in Hypericum perforatum. Journal of Medicinal Chemistry, 45, 47864793. https://doi.org/10.1021/jm0209782 